\title{
First Report of the Electron Micrograph of "Candidatus Liberibacter” Particles on Citrus in Brazil
}

\author{
Francisco A. O. Tanaka ${ }^{1}$, Elliot W. Kitajima ${ }^{1}$, Waldir C. de Jesus Junior ${ }^{2}$, Antonio J. Ayres ${ }^{2}$, Nelson \\ Gimenes-Fernandes ${ }^{2}$ \& Joseph M. Bové ${ }^{3}$
}

${ }^{1}$ Escola Superior de Agricultura “Luiz de Queiroz”, USP, CEP 13418-900, Piracicaba, SP, e-mail: ewkitaji@esalq.usp.br;

${ }^{2}$ Fundo de Defesa da Citricultura (Fundecitrus), CEP 14807-040, Araraquara, SP; ${ }^{3}$ Institut Nationale de la Recherche Agronomique and Université de Bordeaux, BP 81, 33883 Villenave d' Ornon cedex, France

(Aceito para publicação em 05/05/2005)

Autor para Correspondência: Elliot W. Kitajima

\section{RESUMO}

Primeiras observações ultra-estruturais de partículas de "Candidatus Liberibacter” em Citros no Brasil “Candidatus Liberibacter”, agente causal do Huanglongbing (=greening) é detectado pela primeira vez infetando plantas de citros (Citrus spp.) no Brasil e no continente Americano, por microscopia eletrônica.

"Candidatus Liberibacter" is the causal agent of the Huanglongbing (HLB) (= greening), which is considered one of the most important and destructive disease of Citrus spp. in the world. Symptoms similar to HLB were observed in Brazil since March 2004. It is normally confined to some parts of the plant; however it can occurs throughout the tree. Affected sectors show a variety of chlorotic leaf symptoms, poor growth and bear abnormal, distorted and small fruits. A blotchy mottle is the most important leaf symptom for diagnosis. Leaf samples were collected from symptomatic and asymptomatic trees and processed by conventional techniques to be analyzed by electron microscopy. Liberibacter-like particles were found in very low frequency within the sieve tubes of veinlet of symptomatic leaves but not in symptomless leaves (Figure 1A). At higher magnification the envelope characteristic of the "Candidatus Liberibacter" was clearly visible (Figure 1B). The corpuscles were surrounded by two triple-layered membranes, an inner (cytoplasmic) membrane and an outer membrane. Depending upon the plane of the section bacterial all appeared with round to elongated elliptic bacilliform shape. Morphologically, these corpuscles were similar to the presumed "Candidatus Liberibacter" found in sieve tubes of plants affected by HLB and greening (Garnier et al., IOCV Conference 9:115-124. 1984). Two research groups (ColettaFilho et al., Plant dis. 88:1382. 2004; Teixeira et al. Plant dis. 89:107. 2005) detected the "Candidatus Liberibacter" by molecular approach. There is a prevalence of a novel form, designated "Candidatus Liberibacter americanus" (Teixeira et al. Plant dis. 89:107. 2005). The present observation offers visual evidence to the molecular detection and identification of "Candidatus Liberibacter" as the causal agent of HLB-like disease affecting citrus in Brazil.

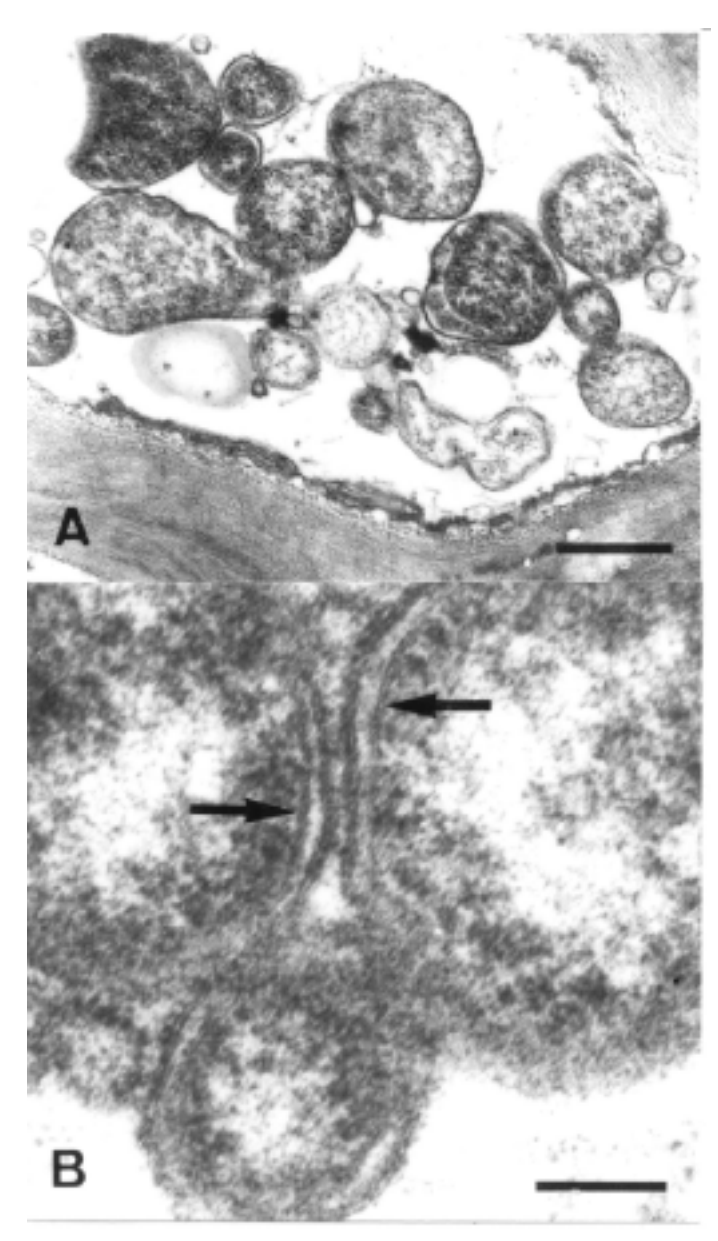

FIG. 1 - A - Liberibacter-like particles in sieve tube on Citrus spp. in São Paulo State, Brazil (Bar $=0,6 \mu \mathrm{m})$ and $\mathbf{B}$ - High magnification of the particles showing the cell membrane (inner) and the outer cell wall (arrows) (Bar $=0,09 \mu \mathrm{m}$ ). 